\title{
Ocular penetration of cephalexin in the rabbit
}

\author{
WALTER E. GAGER, FRED J. ELSAS, AND J. LAWTON SMITH \\ From the Department of Ophthalmology, University of Miami School of Medicine, Miami, Florida
}

The cephalosporin group of antibiotics has gained widespread use in combating resistant infections. Because of the necessity for intravenous administration of cephalothin, and the intramuscular route for cephaloridine, the development of a new member of this series which is effective orally prompted study of its penetration into the eye. This is the first reported study of the passage of cephalexin into the aqueous humour.

\section{Material and methods}

Cephalexin was provided in pure powdered form by the manufacturer through the courtesy of Dr. L. D. Bechtold. Preliminary experiments performed in the Medical Research Laboratory of the Eli Lilly Company had shown that in man nearly 100 per cent. of orally administered cephalexin is absorbed from the gastrointestinal tract within 60 to 90 minutes, and that 98 per cent. is excreted unconjugated in the urine after 6 hours. For the present study, doses of $125 \mathrm{mg}$. powdered cephalexin were dissolved in sterile distilled water and administered by gastric lavage to rabbits. Healthy adult rabbits were weighed, and only animals of the same weight range selected, so that the same dosage was given to all animals- $50 \mathrm{mg} . / \mathrm{kg}$. as a single oral dose. Samples of blood and aqueous humour were then collected at intervals of from $\mathrm{I}$ to 8 hours, and were frozen within 20 minutes after being obtained. Non-toxic pink-topped Vacutainer tubes $\left(\mathrm{NT}_{3206}\right)$ were used for collection and freezing of the blood samples. After topical 0.5 per cent. proparacaine hydrochloride anaesthesia, disposable sterile tuberculin syringes with No. 27 gauge needles were used for anterior chamber paracentesis. Anterior chamber taps were performed only on white and quiet (i.e. non-inflamed) eyes. No paracentesis was repeated on an eye within 48 hours of a previous tap. The specimens were packed in dry ice and shipped via air express to the Lilly Medical Research Laboratories for bioassay. Control sera and aqueous humour samples obtained from normal animals were sent with each shipment. The specimens forwarded to the laboratory were identified by code number only, so that those performing the bioassay determinations had no information concerning time, dose, or which were controls.

\section{Results}

This study consisted of seventy specimens (35 each of serum and matched aqueous humour) from rabbits after oral cephalexin, and eight specimens (4 each of serum and matched aqueous humour) from healthy control rabbits. A total of 78 specimens was thus studied39 serum and 39 aqueous humour. The Sarcina lutea disc-plate technique of bioassay was employed at the Lilly Laboratory, and the results were reported in $\mu \mathrm{g} . / \mathrm{ml}$. No activity was found in any of the eight control specimens. The other data are summarized in the (Table, overleaf) and shown graphically in (Fig. I, overleaf). 
Table Passage of oral cephalexin across blood-aqueous barrier in the rabbit (dose $50 \mathrm{mg} . / \mathrm{kg}$.)

\begin{tabular}{ll}
\hline Time (hrs) & \\
\hline No. of rabbits tested \\
\hline $\begin{array}{l}\text { Serum level } \\
\text { ( } \mu \mathrm{g} . / \mathrm{ml} .)\end{array}$ & $\begin{array}{l}\text { Range } \\
\text { Average }\end{array}$ \\
\hline $\begin{array}{l}\text { Aqueous } \\
\text { humour level } \\
(\mu \mathrm{g} . / \mathrm{ml} .)\end{array}$ & $\begin{array}{l}\text { Range } \\
\text { Average }\end{array}$ \\
\hline
\end{tabular}

Aqueous/serum ratio ( $\mu \mathrm{g} . / \mathrm{ml}$.)

\begin{tabular}{|c|c|c|c|c|c|c|c|}
\hline I & 2 & 3 & 4 & 5 & 6 & 7 & $8 \stackrel{\overrightarrow{0}}{=}$ \\
\hline 5 & 6 & 8 & 6 & 4 & 3 & 2 & $\mathrm{I} \stackrel{\vec{D}}{\square}$ \\
\hline $\begin{array}{l}0-28 \\
16 \cdot 14\end{array}$ & $\begin{array}{l}5 \cdot 1-12 \cdot 5 \\
6 \cdot 24\end{array}$ & $\begin{array}{l}1 \cdot 1-11 \cdot 2 \\
6 \cdot 50\end{array}$ & $\begin{array}{l}0 \cdot 31-20 \cdot 6 \\
5 \cdot 16\end{array}$ & $\begin{array}{l}0 \cdot 76-5 \cdot 3 \\
2 \cdot 0\end{array}$ & $\begin{array}{l}0 \cdot 57-1 \cdot 25 \\
0 \cdot 89\end{array}$ & $\begin{array}{l}0-0.57 \\
0.28\end{array}$ & 30 \\
\hline $\begin{array}{l}0-4 \cdot 4 \\
2 \cdot 35\end{array}$ & $\begin{array}{l}I \cdot 25^{-3} \cdot 0 \\
1 \cdot 95\end{array}$ & $\begin{array}{l}0 \cdot 36-2 \cdot 25 \\
1 \cdot 24\end{array}$ & $\begin{array}{l}0 \cdot 44^{-1} \cdot 6 \\
0.87\end{array}$ & $\begin{array}{l}0 \cdot 26-0 \cdot 70 \\
0 \cdot 5^{1}\end{array}$ & $\begin{array}{l}0.23-0 \cdot 43 \\
0.33\end{array}$ & $\begin{array}{l}0-0 \cdot 46 \\
0 \cdot 23\end{array}$ & o@ \\
\hline $0 \cdot 14$ & $0 \cdot 3^{I}$ & $0 \cdot 19$ & $0 \cdot 15$ & 0.25 & 0.37 & $1 \cdot 2$ & 0 \\
\hline
\end{tabular}

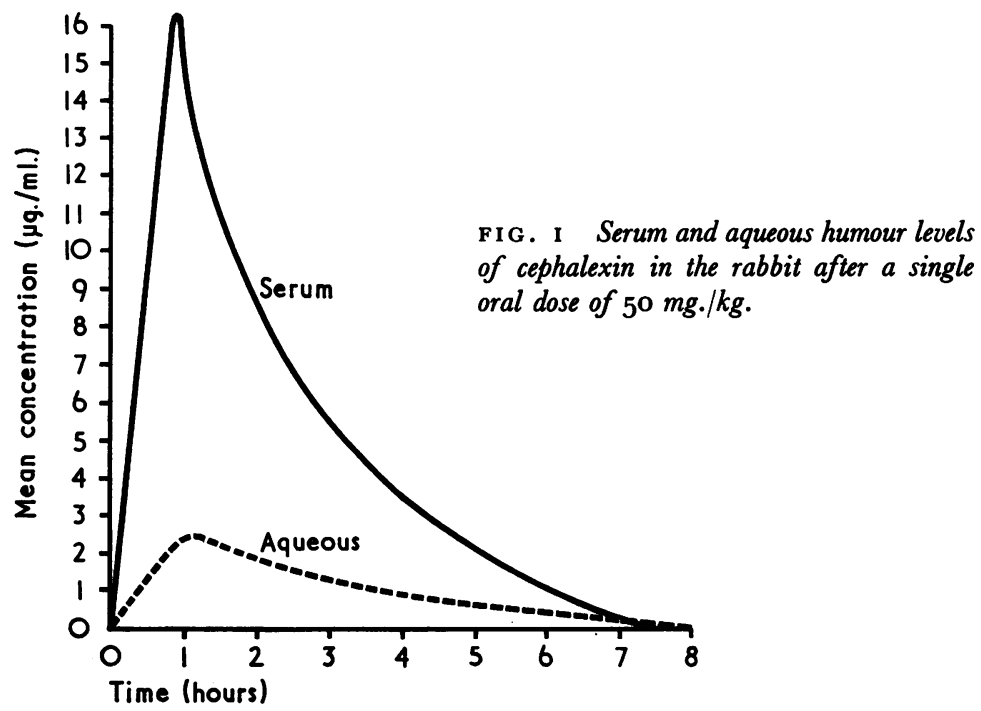

\section{Discussion}

Cephalexin is the generic name for 7-(D-alpha-amino-alpha-phenyl) acetamido/- $3^{3}$ methyl-3-cephem-4-carboxylic acid. It is a white crystalline compound of molecular weight $347 \% 4$. The structural formula is seen in Fig. 2. Cephalexin is a zwitter iop i.e. it has both a basic and an acidic group in the molecule. Because of the presence of both groups, it exists essentially as an inner salt at physiological $\mathrm{pH}$ levels. Cephalexi is stable in both crystalline form and in solution. It is soluble in water to the extent I $3 \mathrm{mg} . / \mathrm{ml}$. at $\mathrm{pH}_{4} \cdot 3$, the isoelectric point. Data from the Lilly Laboratory indicate that cephalexin is comparable to cephaloglycin in activity against Staphylococcus aureus and beta

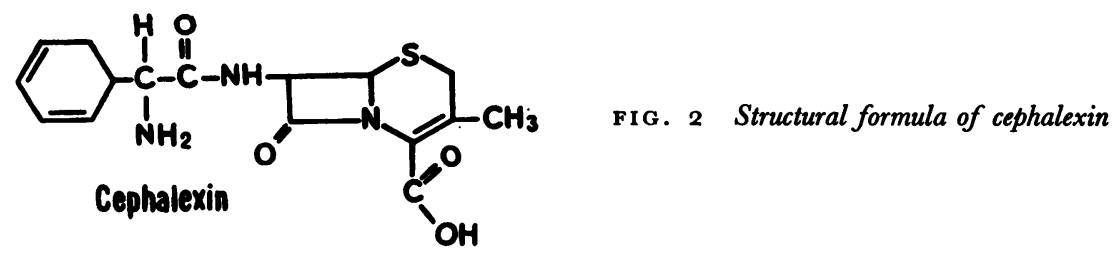


haemolytic streptococci, but less so than cephalothin or cephaloridine. It compares favourably with cephalothin against E. coli, Salmonella, and Shigella. Cephalexin is less potent against Proteus mirabilis than the other cephalosporins, but this organism would be considered to come within its spectrum. The enterococci, other species of Proteus and the Pseudomonas organisms are relatively resistant to all the cephalosporins.

The history of the cephalosporins is of interest. In July, 1945, Prof. Giuseppe Brotzu conducted a search for antibiotic-producing micro-organisms off the coast of Sardinia in the Mediterranean sea. A micro-organism known as Cephalosporium acremonium was found to produce an antibiotic substance in the broth where it was grown. Brotzu (1948) reported his results, and subsequently forwarded the organism to Oxford, England. Abraham, Newton, Schenck, Hargie, Olson, Schuurmans, Fisher, and Fusari (1955) reported the isolation of three different antibiotics from the culture media on which the cephalosporin was produced: a penicillin (cephalosporin $\mathrm{N}$ ), a series of antibacterial steroids (cephalosporin P), and a new antibiotic (cephalosporin C). Chauvette, Flynn, Jackson, Lavagnino, Morin, Mueller, Pioch, Roeske, Ryan, Spencer, and van Heyningen (1962) began to attempt semi-synthetic improvement of the effectiveness and spectrum of cephalosporin $\mathrm{C}$, and the series of semi-synthetic cephalosporins resulted. Cephalothin has been available commercially as Keflin for several years. Cephaloridine has more recently been released as Loridine. Cephaloglycin is now being studied in the United States; preliminary studies by Dr. Robert Sexton (personal communication) are said to have shown reasonable penetration of the aqueous humour by cephalothin, and it was therefore thought reasonable to study this aspect of cephalexin.

Review of the data presented reveals that in the rabbit after a single oral dose of cephalexin $50 \mathrm{mg} . / \mathrm{kg}$., there is a prompt rise in the serum level of the antibiotic, which is highest at one hour, when it averaged $16 \mu \mathrm{g} . / \mathrm{ml}$. The level fell during the second hour to approximately $6 \mu \mathrm{g} . / \mathrm{ml}$., and remained at about this level for the next 2 hours. After the 6 th hour the serum levels fell sharply.

Similarly, cephalexin appeared promptly in the aqueous humour in this species, and maximum levels were found I to 2 hours after administration, with an average level of $2 \mu \mathrm{g} . / \mathrm{ml}$. This fell during the third hour, and was very low after the fourth hour. However, it is seen that cephalexin does enter the aqueous humour in the non-inflamed rabbit eye, and averages about $15^{-20}$ per cent. of the serum level. This is a relatively good passage of an antibiotic across the blood-aqueous barrier, and especially in an agent given by the oral route. No side-effects were observed in the rabbits studied.

It may be mentioned at this point that preliminary investigation of cephalexin in the owl monkey (Aötus trivirgatus) in this laboratory has shown an interesting species difference from the rabbit. In the owl monkey, there is little entry of cephalexin into the aqueous humour during the first hour, but it is seen after 2 hours and appears to be increasing between the third and fifth hours. This was seen although the serum levels had fallen notably between the fourth and fifth hours.

The results obtained in two patients given a single oral dose of cephalexin before ocular surgery might be mentioned. One patient was given $0.5 \mathrm{~g}$. cephalexin by mouth and simultaneous samples of serum and aqueous humour were obtained $2 \frac{1}{2}$ hours later. The serum level was $8 \cdot 20 \mu \mathrm{g} . / \mathrm{ml}$. and the aqueous humour level was $0 \cdot 70 \mu \mathrm{g} . / \mathrm{ml}$. Another patient received a single $\mathrm{I} \cdot \mathrm{o}$ gram oral dose of cephalexin, and specimens obtained $3 \frac{1}{2}$ hours later revealed a serum level of $6 \cdot 20 \mu \mathrm{g} . / \mathrm{ml}$. and an aqueous humour level of $0.78 \mu \mathrm{g} . / \mathrm{ml}$. Thus, in two patients with white and quiet eyes, about 12 per cent. of the serum level was found in the aqueous humour. 
Because of the reported efficacy of cephaloridine in the treatment of patients with earaty syphilis (Glicksman, Short, and Knox, I968), cephalexin was given orally to an o monkey with a histologically proven late syphiloderm and produced prompt healing o lesion which had been present in a chronic state for over 8 months before therapy. It thought that further investigation of cephalexin for use in ophthalmology is indicated.

\section{Summary}

Cephalexin is a new semi-synthetic cephalosporin derivative which possesses the advantage over cephalothin and cephaloridine of being effective when taken by mouth. It is rapidPy absorbed and appears promptly in the aqueous humour of the non-inflamed rabbit ey $\overrightarrow{a E}$. Aqueous humour levels were obtained averaging $15^{-20}$ per cent. of the serum levee Cephalexin merits further investigation in ophthalmology.

Grateful acknowledgment is given to Dr. L. D. Bechtol, Medical Research Division, Eli Lilly and Compan for his help and co-operation with this project.

Dr. W. E. Gager performed this work under a Special Traineeship, National Institute of Neurological Diseaßs and Blindness.

\section{References}

Abraham, E. P., NeWton, G. C. F., SChenck, J. R., haRgie, M. P., Olson, B. H., SchuUrmans, D. FISHER, M. W., and FUSARI, s. A. (1955) Nature (Lond.), 176, 55 I

BRotzu, G. (1948) Lavori Inst. Igiene Univ. Cagliari, 1948-54

ChaUvette, R. R., FlynN, E. H., JACKSON, B. G., LAVAGNino, E. R., MORin, R. B., MUeller, R. PIOCH, R. P., ROESKe, R. W., RYAN, C. W., SPENCER, J. L., and VAN HEYNINGEN, E. (ig62) J. Am chem. Soc., 84, $340 \mathrm{I}$

glicksman, J. M., Short, D. H., and knox, J. M. (1968) Arch. intern. Med., 121, $34^{2}$ 